\title{
Gender Payment Disparities in the European Union
}

\section{Raluca Parjoleanu ${ }^{\star}$}

\begin{tabular}{l}
\hline \multicolumn{1}{c}{ A R T I C L E I N F O } \\
\hline Article history: \\
Accepted November 2020 \\
Available online December 2020 \\
\hline JEL Classification \\
J70, J30 \\
Keywords: \\
Pay gap; Gender inequity; Human \\
resources; Performance; Labour
\end{tabular}

\begin{abstract}
A B S T R A C T
Nowadays, the payment differences between genders for performing the same job is a topic of dispute everywhere on the Globe. More and more female leaders accuse wage discrimination and ask for a comparative analysis of their income against their male colleagues. This article proposes to analise the income differences between genders based on statistical data available at the European Union level and their possible causes.
\end{abstract}

(C) 2020 EAI. All rights reserved.

\section{Introduction}

Nowadays, the inequity of payment has been highlighted by the media. The \#MeToo movement emerged in 2018, based on harassment and assault allegations, and then led to the scrutiny of gender inequality at work, focusing not only on salary discrepancies, but also on the roadblocks that female employees face when they want to get promoted into management role. Also, a number of important and representative lawsuits have brought attention on payment fairness and the payment discrepancies between men and women.

"The United Nations Agenda 2030 for Sustainable Development" identifies among the global strategic objectives "the decrease of disparities and decent work for women and men". The topics of salary raise and salary discrepancies represent the primary focus of the above mentioned agenda. "The Sustainable Development Objective 8" calls for "Promoting sustained, inclusive and sustainable economic growth, full and productive employment and decent work for all" and emphasises the importance of achieving salary equity. "The Sustainable Development Objective 10" aims to "reduce inequalities within and among countries", targets the increase of salaries by $40 \%$ of the disadvantaged, eradicating discrimination and enforcing legal measures that in time will lead to a better level of equity.

\section{Literature review}

Since the publication of "The Economics of Discrimination" (Becker G. S. 1957), research has focused on the topic of the injustice in the economy. Ever since 1957, scientists in the labour field have started to focus their research on the salary differences based on the employee's gender. They have analysed microdata which made possible the estimation of employee productivity and the study of the differences between the payments that the two genders receive for the same work productivity. At first, majority of the research was aimed at the econometric part of the analysis and used data from only one country, focusing on theoretical aspects.

Becker (1964) and then Mincer (1974) have explained the argument related to the payment disparity between genders as being caused a discrepancy in the level of education and know-how in the job field. The researchers based their theory on the fact there are discrepancies between the level of academic instruction of the two genders and the fact that women will have to pause their work trajectory at times to focus on family. They considered that these elements generate a lower level of work experience.

It wasn't until 1998 and 2004 that researchers published the first materials containing metaanalysis. In paper from 1998, Stanley and Jarrell found twelve elements that impacted the differences in payment between men and women in America and those elements were found responsible for $80 \%$ of those differences. In 2004, they republished their paper with additional data analysis.

Experimental research has proven that the differences between people make for the majority of the causes of the "gender pay gap".

In the XXIst century, in most cases, men and women have the same level of access to academic education and training, especially in the modern world, which leads to the conclusion that education cannot 
be the factor behind the "gender pay gap" (World Bank 2012). Nowadays, in most parts of the world, reality shows us that the gender discrepancies in education level are very low or sometimes inverted. Based on this information, we notice that education can't be the reason behind a payment discrepancy and that it is even more important to further analyse what causes the gap. According to the Romanian National Statistics Institute, data shows that in our country 2 to 3 per cent more female employees have a university education as compared to men. Unfortunately, the same data shows these female employees with university education work in domains with lower income levels, like education or public administration, while males with university education will prefer more technical fields which prove to have higher salary levels..

\section{Legislative aspects in the European Union}

One of the main purposes of the "Europe 2020 Strategy" is "Increasing the employment rate for the population currently aged between 20 and 64 from $69 \%$ to at least $75 \%$."

The Romanian employment rate must be increased up to $70 \%$.

Statistics show that the employment rate is smaller in the case of women in the European Union. This is why all member states should be very dedicated to their endeavours of including more women into the labour market. Some of the payment inequity can be explained by nature's order, if we can call it this way, which decided that women are the ones to bring offspring into this world, thus leaving then incapacitated to work for a period of their lives. For this period to become shorter and in order to increase the female employment rate, there is a need for day care/ infant care facilities, a willingness for flexible work conditions from the employer's side, but also raised awareness that household chores are not an attribute of the female gender, but skills for life.

The equity of payment idea is included in the European Union treaties since 1957 and it was redefined in the "Directive 2006/54/EC of the European Parliament and of the Council of 5 July 2006 on the implementation of the principle of equal opportunities and equal treatment of men and women in matters of employment and occupation (recast)". Based on the Article 157 of the "Treaty on the Functioning of the European Union"(TFEU), the above mentioned Directive requires that for "equal work or work of equal value", any type of discrimination based on the sex of the employee must be extinguished. All countries in the European Union have translated this regulation into their local legislation.

Even though the rule of equal salaries has been integrated into EU legislation for more than sixtythree years and it has been transposed in national laws of the countries from the European Union, it has been uncovered in the 2013 "European Commission report on the review of the application of this Directive in the Member States" that there is a real challenge in the enforcement of equal payment. This report has helped surface the main issues standing in the way of putting it into practice.

Figure 1 - Main issues in the way of implementing equal payment

\begin{tabular}{|c|c|c|}
\hline Absence of transparency in pay systems \\
\hline Absence of labour legal stability \\
Procedure issues
\end{tabular}

Source: personal representation

\section{Gender pay differences in the European Union}

The fact that the payment equity rule is not correctly implemented is causing an important and constant difference between gender salaries, which on average was $16.2 \%$ in the European Union. Payment inequity between the two genders, showing that females receive less money than males for the same/ similar tasks is the main component of what is called gender pay gap or gender payment inequity, but other factors also pay a role in this. These factors include gender inequity, job dissociation, a small number of female leaders, and some perpetuated patterns regarding the roles of women, the preponderate distribution of chores to women.

\section{Figure 1 - Gender pay gap evolution in the European Union}

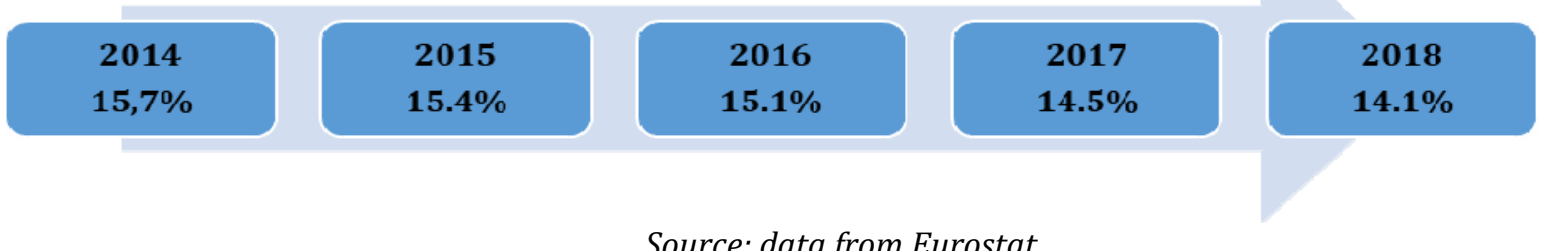


Chart 1 - Relation between the gender salaries in the European Union $(2015,2016,2018)$

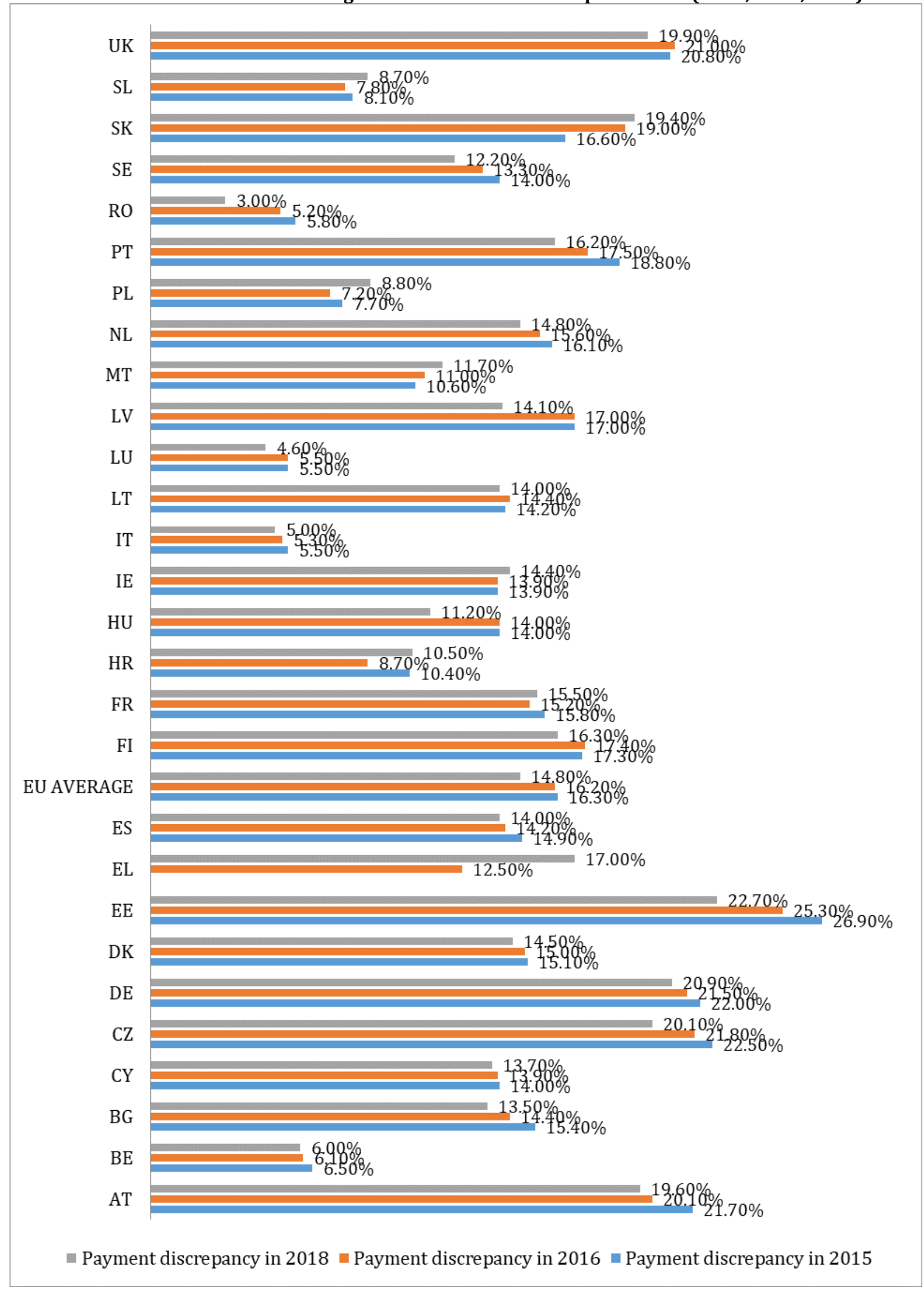

Source: processing of the data available from Eurostat 2016/2018 
Figure 2 - Causes of the Salary discrepancy

\section{Women working in lower-paid fields}

\section{Women working in lower paid jobs}

\section{Poor work - life balance}

\section{Payment discrimination}

Source: personal representation of the data from Eurostat

It should be noted that researchers have uncovered that the salary discrepancy between genders is commonly at a much smaller rate for young employees with a tendency to grow over time. Statistical data shows very different diagrams in the evolution of the payment discrepancies over age from one country to another. This increase in the gap is put mainly on the career breaks that women need to take to balance family and work. Another factor to consider in measuring the gap for older women is that in the first part of their career, employers did not have equity standards in place, basically being able to pay them less without any issue.

In order to show this tendency of discrepancy growth over time, we will take the statistical situation of Spain and Cyprus, where data highlights the widest variations in the salary gap between. The chart 2 below shows the evolution of the "gender pay gap" in Spain and Cyprus.

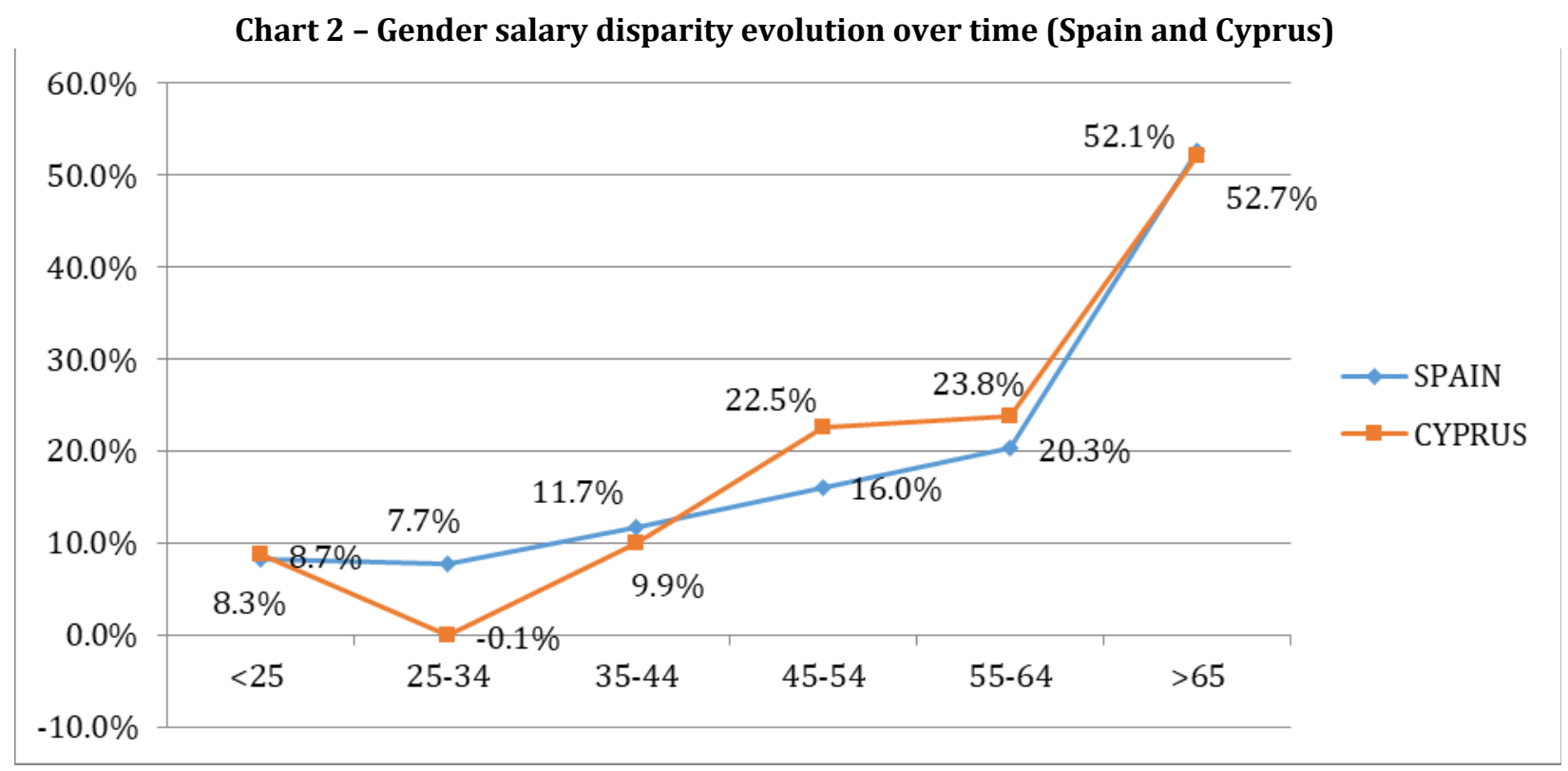

Source: personal representation of data from Eurostat

In Romania's case, the fluctuation has a totally different pattern, as we can see in Chart 3. 
Chart 3 - Gender salary disparity evolution over time in Romania

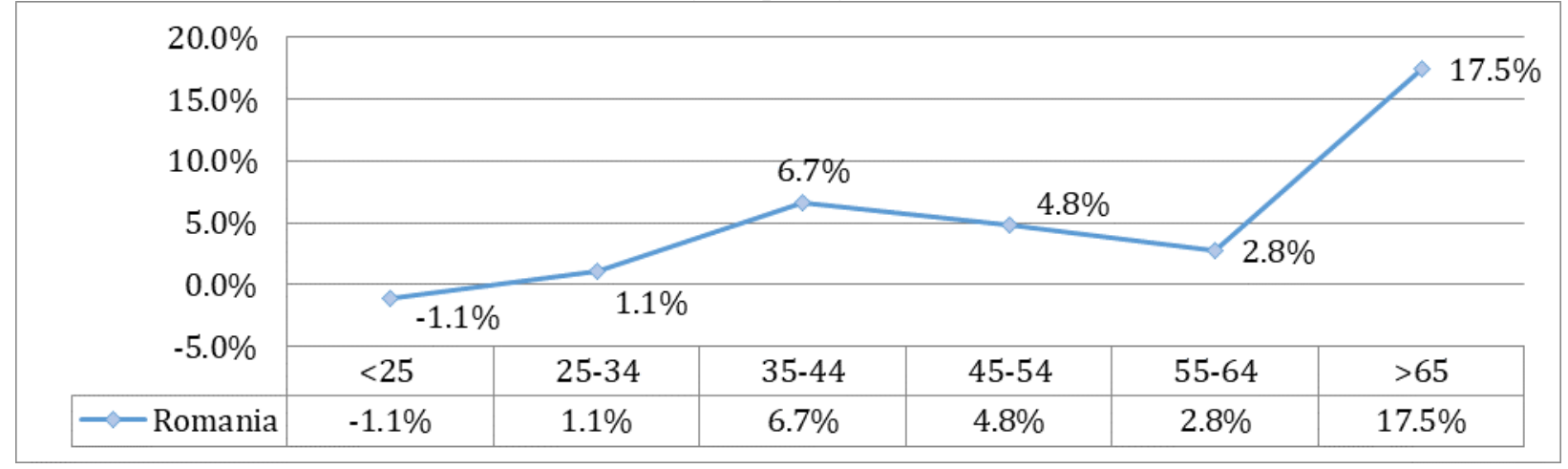

Source: personal representation of data from Eurostat

Eurostat statistical data demonstrates that there is a small reduction trend of the average level of salary discrepancy between genders at European Union level. Thus, the EU average has reduced from $16.3 \%$ and $16.2 \%$ according to the statistical data available for the years 2015 and 2016, down to 14,1\% in 2018 . Nevertheless, there are exceptions between the EU member-states, in which cases the disparities have widen, as can be seen from the table below:

Table 1 - Countries where "gender pay gap" increased (2015 / 2016 / 2018)

\begin{tabular}{||l||c|c||c||}
\hline \hline Country & Gender Pay Gap 2015 & Gender Pay Gap 2016 & Gender Pay Gap 2018 \\
\hline \hline Slovakia & $16,60 \%$ & $19,00 \%$ & $19,40 \%$ \\
\hline \hline Lithuania & $14,20 \%$ & $14,4 \%$ & $14,00 \%$ \\
\hline \hline Malta & $10,60 \%$ & $11,0 \%$ & $11,70 \%$ \\
\hline
\end{tabular}

Source: processing of the data available from Eurostat 2016/2018

Unadjusted statistically, the salary disparities between genders highlight the differences in hourly financial income. Salary disparity can only partially be justified by the personal background of the two genders of the employees (experience and education level) and by the tendency of some sectors to employ mostly only one gender (taking men towards more technical jobs which are better paid). More importantly, the payment disparity between genders has roots in factors which are based on culture, legal system, society and economy which go beyond the topic of receiving the same salary for the same amount of work.

In 2014, Eurostat compared the income per hour of different jobs, in 8 fields as presented in Chart 4 and reached to the conclusion that women received less money in almost all of the countries across the European. The highest gap was identified in the case of those working as Managers (females receive 23\% less than males per hour). The lowest gap was observed in the case of those working as administrative assistants and working in sales (females receive 8\% less than males for both categories), but these are the some of the fields with the lowest levels of income.

Chart 4 - Hourly salary differences in Romania - 2014

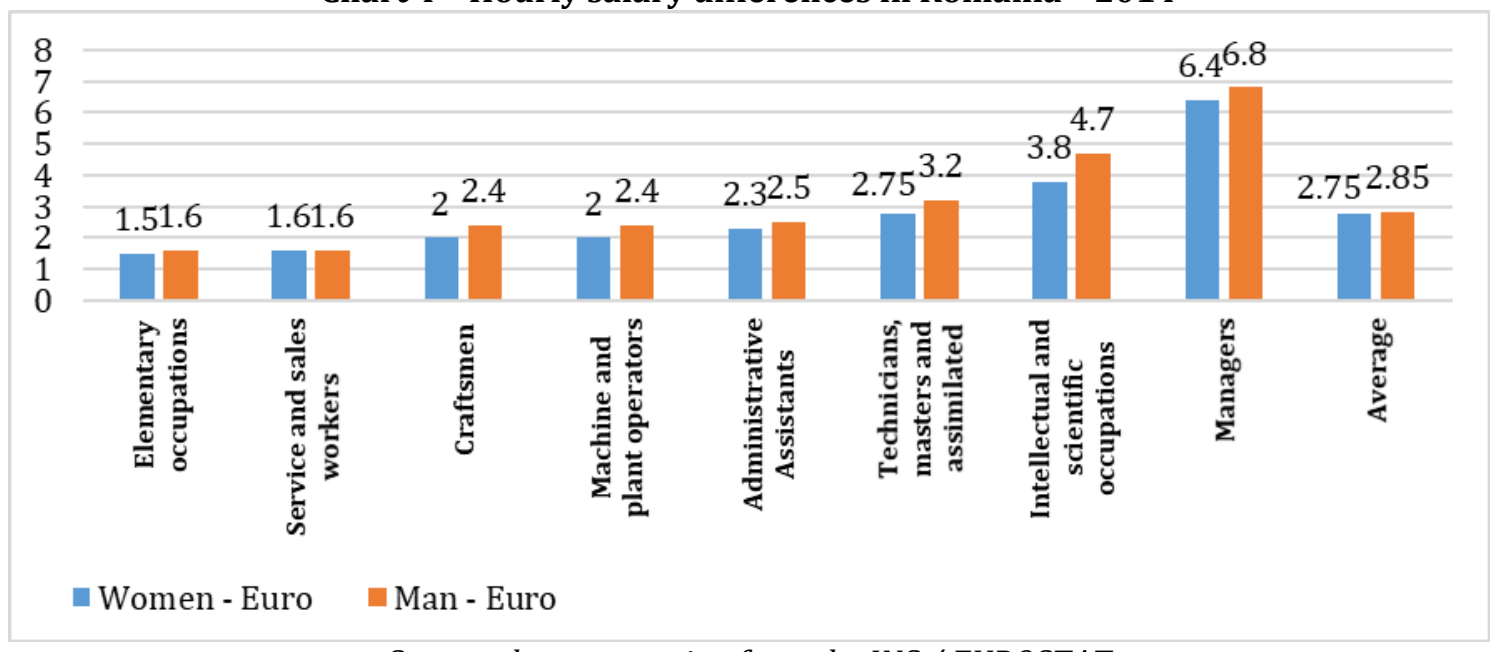

Source: data processing from the INS / EUROSTAT 
As we can observe from the latest available statistical data, in the European Union, there have been changes in the last years. The income discrepancy has changed and the 2018 data is reflected below, in the Chart 5.

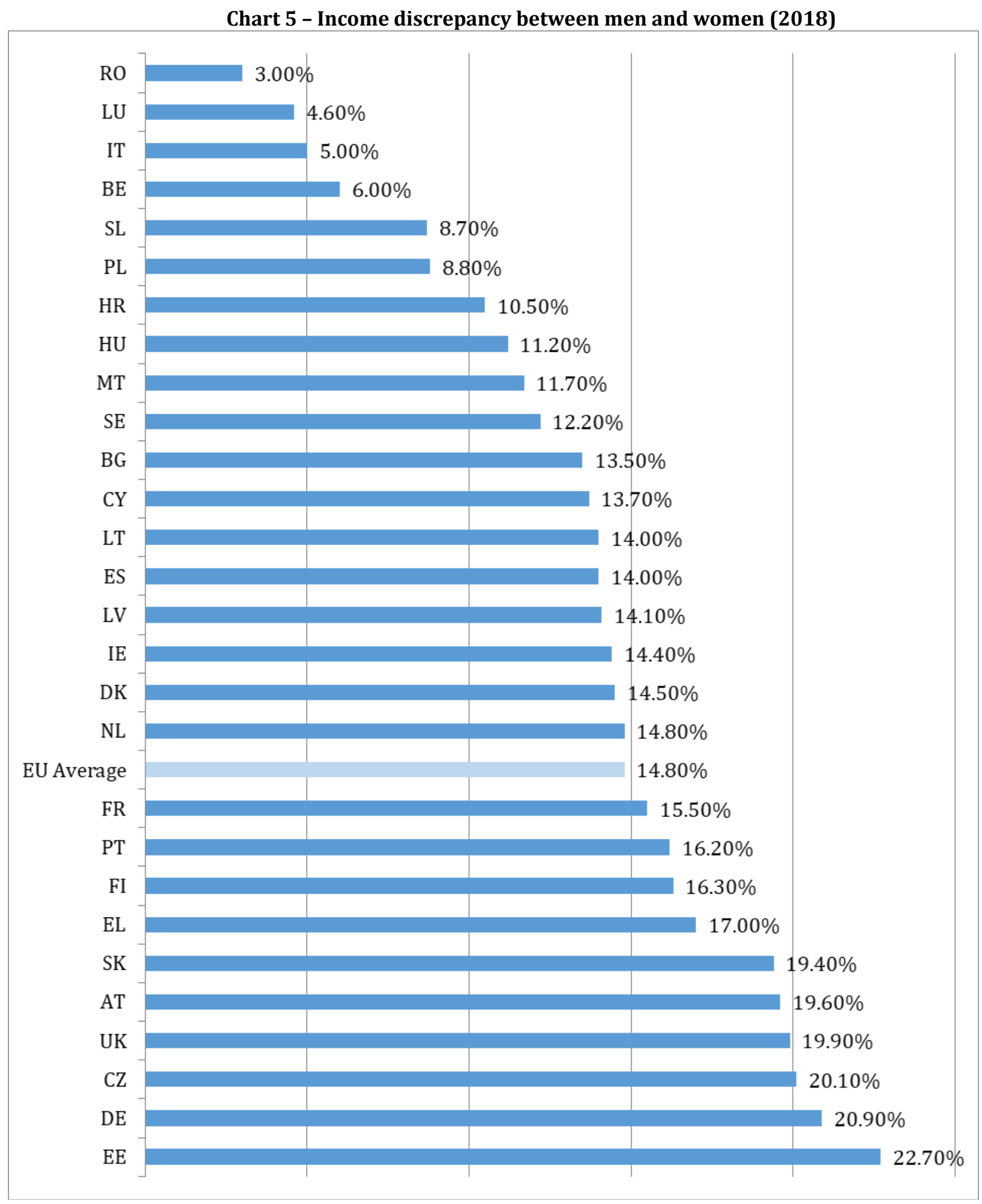

Source: processing of the data available from Eurostat 2018

\section{Perception and reality}

According to a Eurobarometer of the Kantar Public, 90\% of EU citizens declare that they believe it is unacceptable for females to receive less money than male colleagues performing the same work. Another very important thing highlighted is the fact that the $74 \%$ of the European citizens are not aware of the fact that payment equity is a legal right within the European Union.

The study reveals that the majority of women (51\%) and men (58\%) believe that their employer respects the idea of payment equity between genders. It is also interesting to notice that half the Europeans 
do not observe any salary discrimination in the organisation that employs them. One of the reasons behind this perception is based on the salary confidentiality rule that most companies apply, thus colleagues cannot have an accurate image over the incomes of the others.

This should be correlated with the fact that $64 \%$ of European employees militate for the transparent communication of average salaries in their company, based on the type of job. We are presenting in Chart 6 the above mentioned situation at European Union level:

Chart 6 - European employees militate for the transparent communication of average salaries in their company, based on the type of job

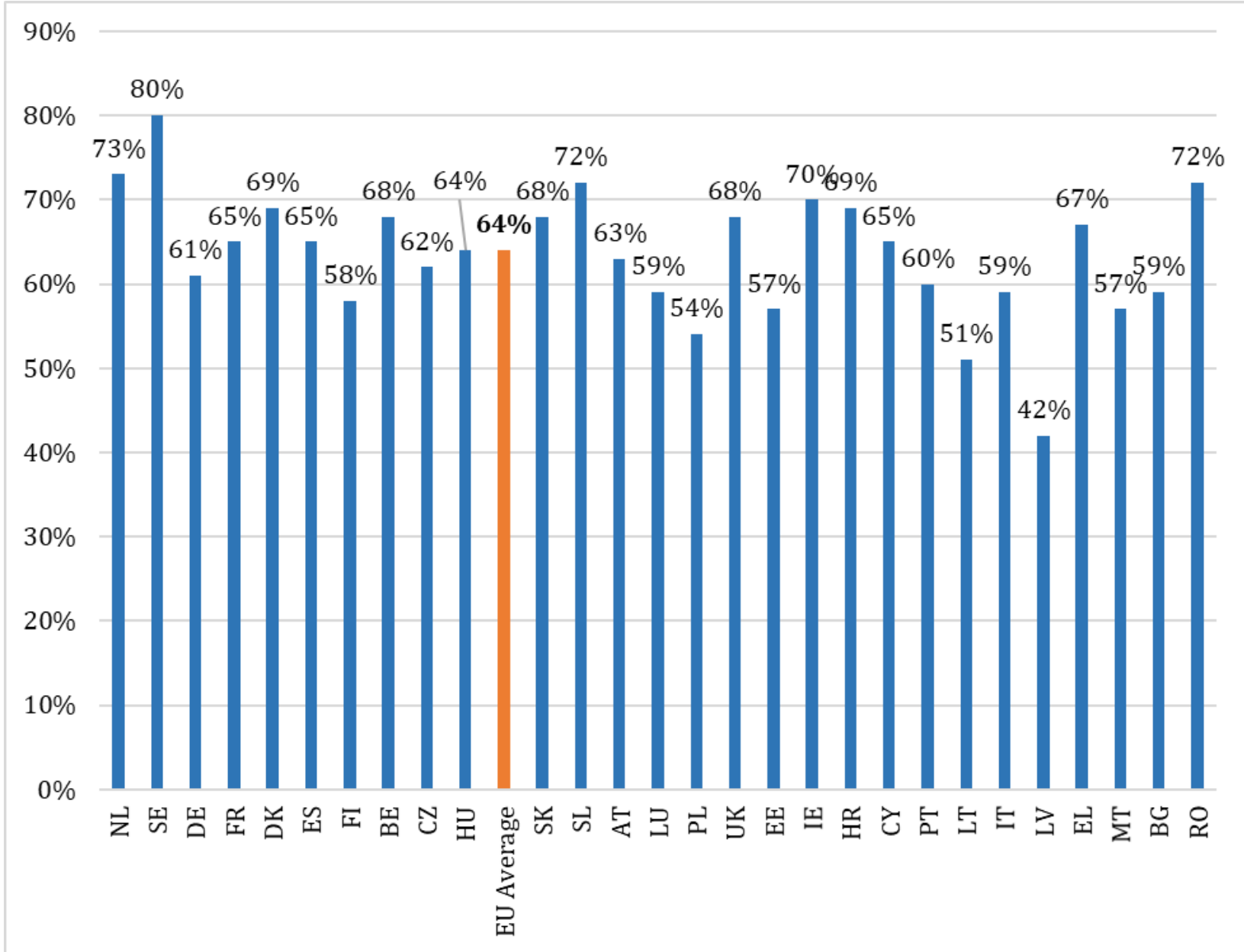

(Source: processing of Eurobarometer data, Kantar Public)

Research shows that the perception of people varies regarding the existence of payment discrepancy between sexes. Thus, $69 \%$ of them believe that females are earning less, $23 \%$ perceive that there is no payment difference, but $2 \%$ think that females receive more money. We're showing in Chart 7 the correlation between the salary discrepancy perceptions and the level of the actual differences registered in European countries.

As mentioned before, the difference between reality and perception is mostly caused by the fact that companies impose on workers a confidentiality agreement to not disclose their salaries to co-workers. This has a perverted effect of either thinking that the others have higher incomes or the other way around - that your salary is higher or equal to the others'. This way, perceptions get distorted and the real discrepancies remain hidden.

The EU banns by law to discriminate between genders when establishing salaries. The European Union Treaty has embedded the "Principle of Equal Pay for the same work and work of equal value for all individuals". The same principle is also reflected in directives, which were transposed in national laws. This should have led to the elimination of payment disparities between genders, but reality shows that it did so only partially. Today, payment equity and equality is still an issue in most counties. 
Chart 7: Correlation of perception and statistical data regarding payment discrepancies

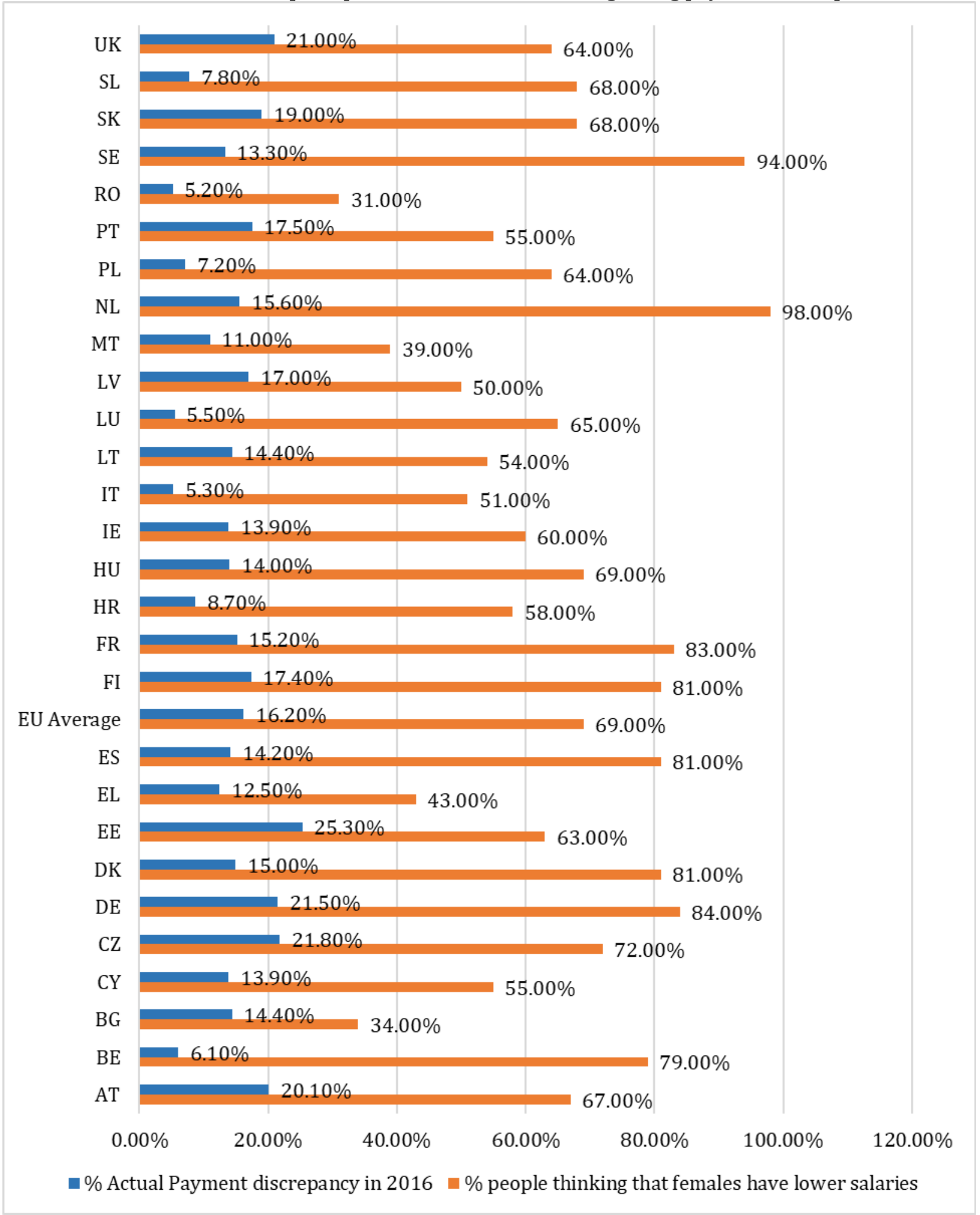

(Source: statistical data processing from EUROSTAT and Eurobarometer)

As shown in the Chart 7, we can identify both types of cases: situations in people are conscientious about the reality and the level of distorted opinion is low - as it happens in Romania, but also situations where reality is that people's awareness is very much distorted and even though there is a small percentage of disparity, people think that women are discriminated - as it happens in Belgium and Luxembourg. The same chart shows us that at European Union level we find the smallest percentage of payment discrepancy in Romania.

It should be noted that employers need to do a much better job at being transparent in payment policies. This would help from two points of view. It would correct employees' awareness on salary differences (whether they exist of not and to what extent) and it would open the discussions so that these 
disparities could be eliminated in the cases where they really exist. This would also lead to a mind shift both for employees, but also for employers.

\section{Conclusions}

One of the first conclusions is that we should not consider the gender payment disparity as a reflection indicator for overall inequality between men and women because, statistically, this takes into account only employees. Also, when analysing payment disparities, a large scale of other indicators and conditions should be included in the equation. The main one to mention is the inclusion of local labour market conditions. For example, if we analyse the situation in countries where the employment rate of women is small, we will notice that the salary discrepancies are low as well, as compared to other counties. But this correlates with the fact that a minimal percentage of women with a small level of skills are actually working.

If we look at labour market structure, statistical data analysis shows that an increased salary discrepancy is more characteristic to those member states where women are focused to work only on a limited number of work domains. Another conclusion is that in those countries many women are part-time employees.

The payment discrepancy can also be affected by local policies and law or rules regarding salary determination.

Another aspect needs to be noted - the fact that in the European Union there are less working women than men. Thus, according to Eurostat data, the difference in employment based on gender was $11.7 \%$ in 2019 , with only $67.3 \%$ of women having a job and $79 \%$ of men being engaged in the labour market.

The hourly salary difference between men and women in the European Union is shown by the latest statistical data to be at $14.1 \%$ and the reduction made in the last ten years is small. It is important to continue to reduce it as much as possible. In order to diminish these disparities, women would need to increase the number of working hours, meaning that they should focus more on full time jobs in order to shift the current tendency of part time job present in over $30 \%$ of women nowadays.

The $14,1 \%$ salary difference translates into the fact that in the European Union a woman receives 14 cents less for every hour worked. If we compute this data, we will reach the conclusion that every year women in the EU do their job for free for 2 months.

The global pandemic in 2020 generated by the Covid19 virus, is putting additional pressure on eliminating the difference in payment between men and women, as we have a higher percentage of women in frontline jobs with small salaries as is the case of those working in institutions that provide care for the elderly or children, those working in the medical system such as therapists or nurses, but also those with cleaning jobs, working in supermarkets or with teaching jobs. The policies must enforce the need for equal share of responsibilities and also for the appreciation of women's skills, efforts and responsibility.

The European Union has to start the enforcement of strict rules and regulations to ensure that the payment disparity between sexes is eliminated. We have member states in the European Union that have already in place laws which facilitate the identification and resolution of cases of payment discrepancies. If we take the example of Iceland, we will discover that islandish law requires companies with more than 25 employees to obtain a certification that demonstrates the salaries are equal of the same amount of work no matter the gender. Another best pranctice example is that of Poland where the government created a free application to be used by employers to detect and measure if there is a payment disparity between men and women within their company.

Such examples must become the norm in the entire European Union. Nevertheless, education from a young age to ensure that people understand that they need to contribute equally in the share of domestic and care responsibilities, is of outmost importance.

\section{References}

1. Blau, D.F., Kahn, M. L. (2007) „The Gender Pay Gap: Have Women Gone as Far as They Can?”, Academy of Management Perspectives, Vol. 21, No. 1, p. 7-23

2. Becker, G. S. (1957) „The Economics of Discrimination”, University of Chicago Press.

3. Jarrell, S. B., Stanley, T. D. (2004) „Declining bias and gender wage discrimination? A meta-regression analysis”, Journal of Human Resources 39(3) p. 828-838

4. Mincer, J. (1974) „Schooling, experience and earnings”, New York: National Bureau of Economic Research.

5. Neumark, D (1988) „Employers' Discriminatory Behaviour and the Estimation of Wage Discrimination”, Journal of Human Resources, 23(3), p. 279-95

6. Oaxaca, R. (1973) „Male-Female Wage Differentials in Urban Labour Markets”, International Economic Review, 14 (3), p. $693-709$.

7. Stanley, T. D., Jarrell, S. B. (1998) „Gender wage discrimination bias? A meta-regression analysis”, Journal of Human Resources 33(4) $p$. 947-973

8. Weichselbaumer, D., Winter-Ebmer, R. (2005) "A Meta-Analysis on the International Gender Wage Gap", Journal of Economic Surveys. 19 (3), p. 479-511.

9. European Commission (2015) „Strategic engagement for gender equality 2016-2019”

10. INS (2016),Femeile si barbatii - parteneriat de munca si viata”

11. https://ec.europa.eu/info/sites/info/files/ebs 465 infographic gender pay gap.pdf accessed 15.11.2018 
12. https://ec.europa.eu/info/policies/justice-and-fundamental-rights/gender-equality/equal-pay/gender-pay-gap-situationeu en\#documents accessed on 21.09.2020

13. https://www.un.org/sustainabledevelopment/development-agenda/ accessed on 21.09.2020

14. https://eur-lex.europa.eu/legal-content/RO/TXT/PDF/?uri=CELEX:52010DC2020\&from=RO accessed on 21.09.2020

15. https://ec.europa.eu/eurostat/statistics-explained/index.php/Gender pay gap statistics accessed on 21.09 .2020

16. http://ec.europa.eu/eurostat accessed 15.11 .2018

17. https://www.un.org/sustainabledevelopment/development-agenda/accessed 15.11.2018

18. https://ec.europa.eu/eurostat/statistics-

explained/images/9/96/The unadjusted gender pay gap by age \%28\%25\%29\%2C 2018.png accessed on 15.09.2020 